\title{
Cloning, sequencing and biochemical characterization of xylose isomerase from Thermoanaerobacterium saccharolyticum strain B6A-RI
}

\author{
YoNG-EOK LeE, ${ }^{1 \dagger}$ MATUR. V. RAMESH ${ }^{2} \ddagger$ and J. GREGORY ZeIKuS ${ }^{1,2 *}$ \\ ${ }^{1}$ Department of Microbiology and Public Health, and ${ }^{2}$ Department of Biochemistry, Michigan State University, \\ East Lansing, MI 48824, USA
}

(Received 18 January 1993; accepted 15 February 1993)

\begin{abstract}
The xylose isomerase gene from Thermoanaerobacterium saccharolyticum strain B6A-RI was cloned by complementation using Escherichia coli $x y l-5$ mutant strain HB101. One positive clone was detected and the recombinant plasmid, pZXI6, was isolated. The clone contained the vector pUC18 and an insert fragment of $4.5 \mathrm{~kb}$. The cloned xylose isomerase gene ( $x y l A)$ was expressed constitutively in $E$. coli. The gene contained one open reading frame (ORF) of $1317 \mathrm{bp}$, which corresponds to 439 amino acid residues. The molecular mass of the gene product was calculated to be $50474 \mathrm{Da}$ from the deduced amino acid sequence. A putative promoter region (Pribnow box), TATAATATATAAT, which repeated twice at the -10 region in $E$. coli, was found 25 bp upstream of the ribosomal binding site. The deduced amino acid sequence of $T$. saccharolyticum strain B6A-RI xylose isomerase exhibited very high homology to those from Thermoanaerobacterium thermosulfurigenes 4B (formerly Clostridium thermosulfurogenes 4B) and Thermoanaerobacter ethanolicus 39E (formerly Clostridium thermohydrosulfuricum 39E). Codon usage in $x y n A, x y n B$ and $x y l A$ showed a clear propensity for AT-containing isocodons. The native molecular mass of the purified recombinant thermostable xylose isomerase was $200 \mathrm{kDa}$, and the enzyme was a tetramer comprised of identical subunits. The apparent temperature and pH optima for activity of the cloned xylose isomerase were $80^{\circ} \mathrm{C}$ and 7.0 to $7 \cdot 5$, respectively.
\end{abstract}

\section{Introduction}

Thermoanaerobacterium saccharolyticum strain B6A-RI is a thermophilic anaerobic bacterium capable of actively degrading xylan. Endoxylanase and $\beta$-xylosidase degrade the polymer to D-xylose, which is isomerized to Dxylulose and further catabolized in the cell. The isomerization of D-xylose is catalysed by D-xylose isomerase (EC 5.3.1.5) which is also used industrially to convert D-glucose to D-fructose syrups (Antrim et al., 1979; Bucke, 1980).

In Bacillus subtilis, the enzymes encoded by the xylose regulon consist of genes for xylan and xylose utilization,

*Author for correspondence. Tel. (517) 353 4674; fax (517) 353 9334.

$†$ Present address: Division of Chemistry and Chemical Engineering, California Institute of Technology, Pasadena, CA 91125, USA.

$\ddagger$ Present address: Ohio State Biotechnology Center, Rightmire Hall, Carmack Road, Ohio State University, Columbus, OH 43210, USA.

The nucleotide sequence data reported in this paper have been submitted to GenBank and assigned the accession number M91248. which cooperate in the utilization of hemicelluloses (Hastup, 1988). These genes are negatively regulated by the repressor $(x y l R)$ and are induced by xylose (Kreuzer et al., 1989). In T. saccharolyticum strain B6A-RI, the endoxylanase and $\beta$-xylosidase activities were induced during growth on xylan and xylose. The synthesis of xylose isomerase from $T$. saccharolyticum was also induced by either xylose or xylan (Y.-E. Lee, S. E. Lowe \& J. G. Zeikus, unpublished data).

There is increasing interest in enzymes which are thermostable and active at high temperatures, and for this reason, thermophiles have received greater attention recently. Xylose isomerase has been purified and characterized from Thermoanaerobacterium saccharolyticum strain B6A (formerly Thermoanaerobacter strain B6A) (Lee \& Zeikus, 1991) and cloned from Thermoanaerobacterium thermosulfurigenes 4B (formerly Clostridium thermosulfurogenes 4B) into E. coli and B. subtilis (Lee et al., 1990). To date, there are no data regarding the genetic organization of the xylose isomerase $(x y l)$ genes in $T$. saccharolyticum strain B6A-RI. We have isolated genes encoding endoxylanase $(x y n A)$ and $\beta$-xylosidase $(x y n B)$ from the genomic library of $T$. saccharolyticum strain B6A-RI, which were found to be organized in a 
cluster on the chromosome (Lee, 1992). In this report, we describe the cloning, sequencing of the $x y l A$ gene from $T$. saccharolyticum strain B6A-RI and discuss its relationships to endoxylanase and $\beta$-xylosidase.

\section{Methods}

Bacterial strains and plasmids. T. saccharolyticum strain B6A-RI (Lee et al., 1993) was used as the source of the xylose isomerase gene. E. coli $\mathrm{xyl}^{-}$mutant strain $\mathrm{HB} 101\left(\mathrm{~F}^{-}\right.$mcrB $m r r$ hsdS2O $\left.\mathrm{r}_{\mathrm{B}}{ }^{-} \mathrm{m}_{\mathrm{B}}{ }^{-}\right]$rec $A 13$ supE44

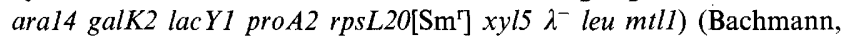
1972) was used as the host strain for cloning by complementation. Plasmid pUC18 was used as the cloning vector.

Chemicals, media and growth conditions. All chemicals were of analytical reagent grade and were of the highest purity available. $T$. saccharolyticum strain B6A-RI was grown under anaerobic conditions at $60^{\circ} \mathrm{C}$ in TYE medium (Zeikus et al., 1980) containing $0.5 \%$ xylose as a carbon source. For growth of $E$. coli strains, Luria broth $(10 \mathrm{~g}$ tryptone, $5 \mathrm{~g}$ yeast extract, and $5 \mathrm{~g} \mathrm{NaCl}$ per litre) was used for liquid culture, and solid medium contained $1.5 \%(\mathrm{w} / \mathrm{v})$ agar (Difco). Ampicillin $\left(50 \mu \mathrm{g} \mathrm{ml}^{-1}\right)$ was supplemented for the selection of transformants. MacConkey agar (Difco) plates containing $1 \%(\mathrm{w} / \mathrm{v})$ xylose were used to detect xylose isomerase positive clones.

DNA preparation and cloning procedure. Chromosomal DNA of $T$. saccharolyticum strain B6A-RI was isolated by a modification of the method of Marmur (1961). Plasmid DNA was purified in large scale by the procedure described by Clewell (1972), followed by centrifugation in a caesium chloride/ethidium bromide density gradient. The alkaline denaturation method of Birnboim \& Doly (1979) was used for rapid extraction of plasmid DNA.

Chromosomal DNA from $T$. saccharolyticum strain B6A-RI was partially digested with restriction endonuclease $A c c \mathrm{I}$ and 4-10 kbp DNA fragments were isolated from an agarose gel by electroelution, using the elutrap (Schleicher \& Schuell). Plasmid vector pUC18 was completely digested with $A c c$ I and dephosphorylated with calf intestinal alkaline phosphatase. Ligation was performed by the procedure of Sambrook et al. (1989) and transformed into E. coli HB101 competent cells prepared by the Hanahan method as described by Perbal (1988). Transformants were selected on MacConkey agar plates supplemented with $1 \%(\mathrm{w} / \mathrm{v})$ xylose and ampicillin.

Sequence determination of the xylA gene. The recombinant plasmid was denatured by the method of Zhang et al. (1988), and the nucleotide sequence was determined by the dideoxy chain termination method (Sanger et al., 1977), using a Sequenase version 2.0 kit (United States Biochemical). The sequence information was analysed using the GENEPRO software package (Hoefer Scientific Instruments) and the University of Wisconsin Genetics Computer Group GCG package (Devereux et al., 1984).

Enzyme assay. Cell extracts prepared by sonication and purified preparations were used as enzyme sources, and glucose isomerase and xylose isomerase activities were measured as described by Lee $e t$ al. $(1990 b)$.

Purification of xylose isomerase. Xylose isomerase was purified from a 1 litre overnight culture of $E$. coli (pZXI6) cells as described by Lee et al. $(1990 b)$.

Protein determination and SDS-PAGE. Protein was measured by the method of Bradford (1976) using the Bio-Rad protein reagent and BSA (Sigma) as the standard. Enzyme fractions were analysed by SDSPAGE in $12 \%(\mathrm{w} / \mathrm{v})$ polyacrylamide gels in a Mini-PROTEAN II system (Bio-Rad). Protein bands were visualized by Coomassie brilliant blue staining.

$N$-terminal amino acid sequence determination of xylose isomerase. The protein was prepared and analysed as described previously (Lee $e t$ al., 1990b).

\section{Results}

\section{Cloning of the xylose isomerase gene}

The xylose isomerase gene from $T$. saccharolyticum strain B6A-RI was cloned by complementation using $E$. coli $x y l-5$ mutant strain HB101. Transformants were screened on MacConkey agar plates supplemented with $1 \%(\mathrm{w} / \mathrm{v})$ xylose and ampicillin. One positive clone which gave a red colour on this plate was detected and the recombinant plasmid, pZXI6, was isolated. The clone contained vector pUC18 and an insert fragment of $4.5 \mathrm{~kb}$ (Fig. 1). The orientation of the fragment of T. saccharolyticum strain B6A-RI chromosomal DNA in the vector did not affect the level of xylose isomerase activity (data not shown), suggesting that the cloned $x y l A$ gene from $T$. saccharolyticum strain B6A-RI was expressed in E. coli by its own promoter. In T. saccharolyticum strain B6A$\mathrm{RI}$, xylose isomerase activity was induced by D-xylose, whereas in $E$. coli the cloned $x y l A$ was expressed constitutively and addition of D-xylose to the medium did not increase production (data not shown).

\section{Nucleotide sequence of the xylA gene}

The nucleotide sequence and deduced amino acid sequences are shown in Fig. 2. The computer analysis of the nucleotides sequenced revealed one ORF of $1317 \mathrm{bp}$, which corresponds to 439 amino acid residues. This was confirmed as the correct reading frame for the $T$. saccharolyticum strain B6A-RI $x y l A$ gene by comparison of the N-terminal amino acid sequence (underlined in Fig. 2), with that determined for the cloned xylose isomerase purified from $E$. coli (pZXI6).

The ATG initiation codon is preceded, with a spacing of $7 \mathrm{bp}$, by a putative ribosomal binding sequence AAGGAGG which is complementary to the $3^{\prime}$ end of

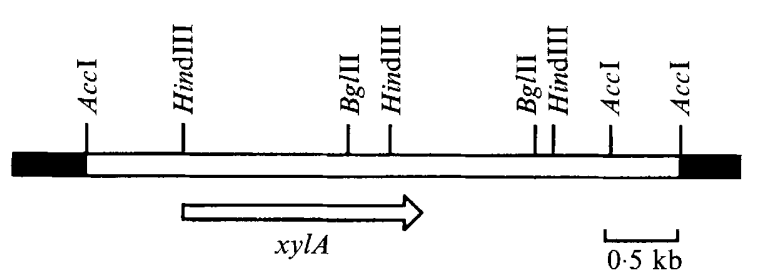

Fig. 1. The physical map of pZXI6 containing vector pUC18 with the insert fragment containing the xylose isomerase gene. 
61 TTAAAATT"TTTATTATGAAGAAGGATTTTAAATTTGTGTAGAATA

121 ATGAAAGAAGGACAGACAAÄGAATAGAAGGAGGAAGCTPTATGAATAAATATTTTGAGA

181 ACGTATCTAAAATAAAATATGAAGGACCAAAATCAAATAÄTCCTTATTCCTTTAAATTTT snValSerLysI leLysTYrGluGlyProLysSerAsnAsnProTyrSerPheLysPheT

241 ACAATCCAGÄGGAAGTAATCGATGGCAAGÄCGATGGAGGÄGATCTCCGCTTTTCTATÁ yrAsnProGlugluVaIIIeAspGlyLysThrMetGluGluHisLeuArgPheSerIleA

301 CTTATTGGCÁCACTTTTACTGCTGATGGAACAGATCAATTTGGCAAGGCTACTATGCAAA laTyrTrpH isThrPheThrAlaAspGIYThrAspG InPheGlyLySA laThrMetGlnA

361 GACCATGGAÁCCACTACACÄGATCCTATGGATATAGCGAAACGAAGGGTÁGAAGCAGCAT rgProTrpAsnHisTyrThrAspProMetAspIleAlaLysArgArgValGluAlaAlaP

421 TTGAGTTTTTTGATAAGATAAATGCACCTTTCTTCTGCTTCCATGATAGGGATATTGCCC heGluPhePheAspLysIleAsnAlaProPhePheCysPheHisAspArgAspIleAlaP

481 CTGAAGGAGÄTACTCTTAGAGAGACAAACAAAAACTTAGATACAATAGTTGCTATGATAA rOGluGlyAspThrLeuArgGluThXAsnLYSAsNLeuAspThrIleValAlaMetrleL

541 AGGATTACTTAAAGACCAGCAAGACAAAAGTTTTGTGGGGTACCGCAAATCTTTTCTCCA YSAsPTYrLeuLysThrSerLysThrLYsValLeuTrPGIYThrA IaAsnLeuPheSerA

601 ATCCGAGATTTGTACATGGTGCATCAACATCCTGCAATGCTGACGTTTTTGCATATTCTG snProArgPheValHisGlyAlaSerThrSerCysAsnAlaAspValPheAlaTyrSexA

661 CAGCGCAAGTCAAAAAAGCCCTTGAGATTACTAAGGAGCTTGGCCGCGAAAACTACGTAT laAlaGInVaILYSLYSAlaLeuGluIleThrLysGluLeuGlyArgGIuAsnTyrValP

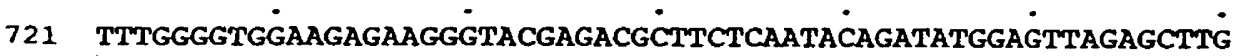
heTxpGIYGIYArgGluGlYTYRGIUThrLeuLeuAsnThrAspMetGluLeuGluLeuA

781 ATAACTTTGCAAGATTTTMGCACATGGCTGTTGACTATGCंAAAGAAATCGGCTTTGAAG spAsnPheAlaArgPheLeuHisMetAlavalAspTyrA laLysGIuI leGIyPheGlug 
841 GTCAGTTCTTGATTGAGCCGAAGCCAAAGGAGCCTACAAAACATCAATACGACTTTGACG lyGInPheLeuI leGluProLysProLysGIuProThrLysH isGInTyrAspPheAspV

901 TGGCAAATGTATTGGCATTCTTGAGAAAATACGACCTTGACAAATATTTCAAAGTAAATA

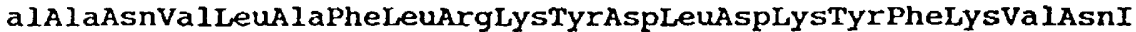

961 TCGAAGCAAACCATGCGACATTGGCATTCCACGACTTCCAACATGAGCTAAGATACGCCA leGluAlaAsnHisAlaThrLeUAlaPheHisAspPheGInHisGluLeuArgTyrAlaA

1021 GAATAAACGGTGTATTAGGATCAATTGACGCAAATACAGGCGACATGCTTTTGGGATGGG rgIleAsnGIYValLeuglySerIleAspAlaAsnThrGlyAspMetLeuLeuglyTrpA

1081 ATACGGACCAGTTCCCTACAGATATACGCATGACAACGCTTGCTATGTAT́tGAATCATAA spThrAspGlnPheProThrAspI leArgMetThrThrLeUAlaMetTyrGluValIlel

1141 AGATGGGTGGATTTGACAAAGGTGGCCTTAACTTTGATGCAAAAGTAAGACGTGCTTCAT ysMetGlYGIYPheAspLYsGIYGIYLeUAsnPheAsPAlaLysValArgArgAlaSerP

1201 TTGAGCCAGAAGATCTTTTCTTAGGTCACATAGCAGGAATGGATGCTTTTGCAAAAGGCT heGluProGIUASPLeUPheLeUGlyHisIleAlaGlyMetAspAlaPheAlaLysGlyP

1261 TTAAAGTGCTTACAAGCTTGTGAAAGATGGCGTATTTGÄCAAGTTCATCGAAGAAAGAT heLysVa lAlaTyrLysLeuValLysAspGlyValPheAspLysPheIleglugluArgT

1321 ACGCAAGCTACAAAGAAGGCATTGGCGCTGATATTGTAAGCGGTAAAGCTGACTTCAAGA yrAlaSerTyrLysGluGlyIleGIYAlaAspI leValSerGlyLysA laAspPheLysS

1381 GCCTTGAAAAGTATGCATTAGAGCACAGCCAGATTGTAAAंCAAATCAGGCAGACAAGAGC erLeuGIULYSTYXAlaLeuGluHisSerGInI IeVaIAsnLYSSerGlyArgGInGluL.

1441 TATTAGAATCAATCCTAAATCAGTATTTGTTTGCAGAATAATGAAACATGAGGGCGGCTT euLeuGluSerI leLeuAsnGInTyrLeuPheAlaGluEndEnd

\section{GgATAGATTTAGgGaCATCATCAGTTAAGATAATACTGATG 1601}

Fig. 2. The nucleotide sequence and deduced amino acid sequence of the cloned xylose isomerase. The computer analysis of the nucleotides sequenced revealed one open reading frame (ORF) of $1317 \mathrm{bp}$ which corresponds to 439 amino acid residues. The underlined region denotes the correct reading frame for the T. saccharolyticum strain B6A-RI $x y l A$ gene by comparison of the Nterminal amino acid sequence determined from the xylose isomerase purified from $T$. saccharolyticum strain B6A (formerly Thermoanaerobacter strain B6A) (Lee \& Zeikus, 1991).

both the E. coli and B. subtilis $16 \mathrm{~S}$ ribosomal RNAs (McLaughlin et al., 1981; Stormo et al., 1982). A putative -10 promoter region (Pribnow box),
TATAATATATAAT, which repeated twice at the -10 region in $E$. coli, was found $25 \mathrm{bp}$ upstream of the ribosomal binding site. 
Table 1. Relative homology between xylose isomerase from $T$. saccharolyticum strain B6A-RI and other xylose isomerases

\begin{tabular}{lcc}
\hline \hline Strain & $\begin{array}{c}\text { Similarity } \\
(\%)\end{array}$ & $\begin{array}{c}\text { Identity } \\
(\%)\end{array}$ \\
\hline B. subtilis & $82.5 \%$ & $69 \cdot 6 \%$ \\
E. coli & $64 \cdot 0 \%$ & $45 \cdot 9 \%$ \\
Thermus thermophilus & $51 \cdot 1 \%$ & $30.5 \%$ \\
S. rubiginosus & $49 \cdot 9 \%$ & $26.5 \%$ \\
S. violaceoniger & $48.3 \%$ & $26.4 \%$ \\
T. thermosulfurigenes 4B & $99 \cdot 1 \%$ & $98.2 \%$ \\
(C. thermosulfurogenes) & & \\
Thermoanaerobacter ethanolicus 39E & $\mathrm{ND}$ & $90 \cdot 4 \%$ \\
(C. thermohydrosulfuricum) & & \\
\hline \hline
\end{tabular}

ND, Not determined.
Comparison of amino acid sequences

The deduced amino acid sequence of xylose isomerase from $T$. saccharolyticum strain B6A-RI was compared to those of $T$. thermosulfurigenes 4B (Lee et al., 1990b), Thermoanaerobacter ethanolicus 39E (formerly Clostridium thermohydrosulfuricum 39E) (Dekker et al., 1991 b), E. coli (Schellenberg et al., 1984), B. subtilis (Wilhelm \& Hollenberg, 1985), Streptomyces violaceoniger (Drocourt et al., 1988), Streptomyces rubiginosus (Wong et al., 1991) and Thermus thermophilus (Dekker et al., 1991a) and the results are shown in Table 1.

The length of the polypeptide chain encoded by the $x y l A$ gene in $T$. saccharolyticum strain B6A-RI was identical to that of $T$. thermosulfurigenes $4 \mathrm{~B}$ (439 amino

(1) MNKYFENVSKIKYEGPKSNNPYSFKFYNPEEVIDGKTMEEHLRF IAYWH

(2) MNKYFENVSKIKYEGPKSNNPYSFKFYNPEEVIDGKTMEEHLRFS IAYWH

(3) -MEYFKNVPQIKYEGPKSNNPYAFKFYNPDE I IDGKP LKEHLRF SVAYWH

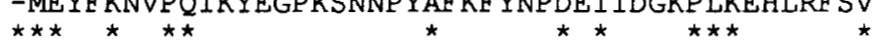

(1) TETADGTDQFGKATMORPWNHYTDPMDIAKRRVEAAFEFFDKINAPFFCF

(2) TFTADGTDQFGKATMQRPWNHYTDPMDIAKARVEAAFEFFDKINAPYFCE TFTANGTDPFGAPTMORPWDHFTDPMD IAKARVEAAFELEEKLDVPFFCF

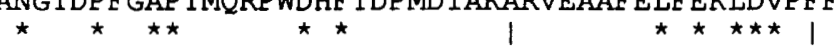

(1) HDRDIAPEGDTLRETNKNLDT IVAMIKDYLKTSKTKVLWGTANLF SNPRF

(2) HDRD IAPEGDTLRETNKNLDTIVAMIKDYLKTSKTKVLWGTANLF SNPRE

(1) VHGASTSCNADVFAYSAAQVKKALE ITKELGRENYVFWGGREGYETLLNT

(2) VHGASTSCNADVFAYSAAOVKKALE I TKELGGENYVFWGGREGYETLLNT

(3) VHGAAT SCNADVEAYAAAQVKKALEI TKEIGGQNYVFWGGREGYETLLNT

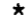
॥

(1) DMELELDNFARF LHMAVDYAKE I GFEGQF L IEPKPKEPTKHOYDFDVANV

(2) DMEFELDNFARF LHMAVDYAKE IGKEGQF I IEPKPKEP TKHQYDFDVANV

(3) DMELELDNLARF LHMAVEYAOE I GFEGOFLIEPKPKEP TKHOYDFDAASV

(1) LAFLRKYDLDKYFKVNIEANHATLAFHDFOHELRYARINGVLGSIDANTG

(2) LAFLRKYDLDKYFKVNIEANHATLAFHDFQHELRYARINGVLGS IDANTG HAFIKKYDIDKYFKLNIEANHAT $\star$ $\star \star$

(1) DMLLGWDTDQFPTD IRMTTLAMYEVIKMGGEDKGGLNFDAKVRRASFEPE

(2) DMLIGWDTDOEPTD IRMT TLAMYEVIKMGGEDKGGLNEHAKVRRASEEPE

(3) DMLLGWDTDQYPTD IRMTTLAMYEVIKMGGFNKGGLNEDAKVRRASFEPE

(1) DLFLGHIAGMDAFAKGFKVAYKLVKDGVFDKE IEERYASYKEGIGADIVS

(2) DLFLGHIAGMDAFAKGEKVAYKLVKDRVFDKEIEERYASYKDGIGADIVS

400

(3) DLFLGHIAGMDAFAKGEKVAYKLVKDGVFDRF IEERYKSYKEGIGAEIVS

(1) GKADEKSLEKYALEHSOIVNKSGRQELLESILNQYLFAE

(2) GKADFKSLEKYALERSQIVNKSGRQELLESILNQYLFAE

(3) GKANFKTLEEYALNNPKIENKSGKQELLESILNQYLFSE

Fig. 3. Comparison of the predicted xylose isomerase amino acid sequence of: (1) $T$. saccharolyticum strain B6A-RI, (2) $T$. thermosulfurigenes 4B (C. thermosulfurogenes 4B), (3) Thermoanaerobacter ethanolicus 39E (C. thermohydrosulfuricum 39E). Bars under the sequences indicate amino acids which are different in the sequence from $T$. saccharolyticum strain B6A-RI and T. thermosulfurigenes 4B, and the stars indicate differences between the sequence of $T$. saccharolyticum and Thermoanaerobacter ethanolicus 39E. 
acid residues) and was similar to those of Thermoanaerobacter ethanolicus 39E (438 residues), and E. coli and $B$. subtilis (440 residues), whereas the enzymes from S. violaceoniger, Ampullariella and Arthrobacter have polypeptides which are shorter by 47 residues at the $\mathrm{N}$-terminal. The deduced amino acid sequence of $T$. saccharolyticum B6A-RI xylose isomerase exhibits very high homology to those from $T$. thermosulfurigenes $4 \mathrm{~B}$ and Thermoanaerobacter ethanolicus 39E ( $98 \%$ and $89 \%$ identity, respectively) and their sequence alignment is shown in Fig. 3.

Codon usage in $x y n A, x y n B$ and $x y l A$

Table 2 summarizes codon usage in the three genes from

Table 2. A comparison of the codon usage frequency in the three genes from $T$. saccharolyticum strain B6A-RI which are involved in xylan degradation

\begin{tabular}{|c|c|c|c|c|c|}
\hline \multirow{3}{*}{$\begin{array}{c}\text { Amino } \\
\text { acid }\end{array}$} & \multirow[b]{3}{*}{ Codon } & \multicolumn{4}{|c|}{ Frequency of codon usage ( $\mathrm{mol} \%)$} \\
\hline & & \multicolumn{3}{|c|}{ T. saccharolyticum strain B6A-RI } & \multirow[b]{2}{*}{ E. col } \\
\hline & & $x y n A$ & $x y n B$ & $x y l A$ & \\
\hline \multirow[t]{2}{*}{ Phe } & TTT & $2 \cdot 8$ & $5 \cdot 6$ & $5 \cdot 2$ & $1 \cdot 3$ \\
\hline & TTC & $0 \cdot 4$ & $1 \cdot 0$ & $3 \cdot 0$ & $2 \cdot 2$ \\
\hline \multirow{6}{*}{ Leu } & TTA & $2 \cdot 1$ & $1 \cdot 4$ & 1.6 & 0.7 \\
\hline & TTG & 1.7 & $2 \cdot 0$ & 1.8 & 0.9 \\
\hline & CTT & 1.4 & $2 \cdot 0$ & $3 \cdot 0$ & 0.8 \\
\hline & CTC & 0 & 0.4 & 0.5 & 0.8 \\
\hline & CTA & $0 \cdot 1$ & $0 \cdot 4$ & 0.7 & 0.2 \\
\hline & CTG & $0 \cdot 6$ & $0 \cdot 2$ & 0 & $6 \cdot 8$ \\
\hline \multirow{3}{*}{ Ile } & ATT & $3 \cdot 3$ & $2 \cdot 4$ & $1 \cdot 6$ & $2 \cdot 2$ \\
\hline & ATC & $0 \cdot 6$ & $0-8$ & $1 \cdot 1$ & $3 \cdot 7$ \\
\hline & ATA & $3 \cdot 4$ & $3 \cdot 4$ & $2 \cdot 3$ & $0 \cdot 2$ \\
\hline Met & ATG & $1 \cdot 8$ & $2 \cdot 2$ & $2 \cdot 7$ & $2 \cdot 8$ \\
\hline \multirow[t]{4}{*}{ Val } & GTT & $3 \cdot 1$ & $2 \cdot 2$ & $1 \cdot 1$ & $2 \cdot 9$ \\
\hline & GTC & $0 \cdot 3$ & $1 \cdot 0$ & 0.5 & $1 \cdot 2$ \\
\hline & GTA & $2 \cdot 8$ & $2 \cdot 4$ & $2 \cdot 7$ & $1 \cdot 8$ \\
\hline & GTG & $1 \cdot 0$ & $1 \cdot 8$ & $0 \cdot 5$ & $2 \cdot 2$ \\
\hline \multirow[t]{6}{*}{ Ser } & TCT & $2 \cdot 4$ & $1 \cdot 4$ & 0.7 & $1 \cdot 3$ \\
\hline & TCC & $0 \cdot 2$ & 0.4 & 0.7 & $1 \cdot 5$ \\
\hline & TCA & $2 \cdot 0$ & 1.0 & 1.4 & 0.4 \\
\hline & TCG & 0.4 & $0 \cdot 2$ & 0 & $0 \cdot 6$ \\
\hline & AGT & 1.5 & 0.4 & 0 & 0.3 \\
\hline & $\mathrm{AGC}$ & $1 \cdot 2$ & $1 \cdot 2$ & $1 \cdot 1$ & $1 \cdot 4$ \\
\hline \multirow[t]{4}{*}{ Pro } & CCT & $1 \cdot 2$ & $2 \cdot 0$ & $1 \cdot 4$ & 0.5 \\
\hline & $\mathrm{CCC}$ & $0 \cdot 2$ & 0.2 & 0 & $0 \cdot 3$ \\
\hline & CCA & 1.9 & $2 \cdot 4$ & $1 \cdot 1$ & $0 \cdot 7$ \\
\hline & $\mathrm{CCG}$ & $0 \cdot 4$ & $0 \cdot 8$ & $0 \cdot 5$ & $2 \cdot 5$ \\
\hline \multirow[t]{4}{*}{ Thr } & ACT & $2 \cdot 9$ & $1 \cdot 2$ & $1 \cdot 1$ & $1 \cdot 1$ \\
\hline & $\mathrm{ACC}$ & 0.4 & $0 \cdot 6$ & 0.5 & $2 \cdot 4$ \\
\hline & ACA & $3 \cdot 6$ & $2 \cdot 0$ & $2 \cdot 7$ & $0 \cdot 3$ \\
\hline & ACG & $1 \cdot 1$ & $1 \cdot 0$ & $0 \cdot 9$ & $0 \cdot 8$ \\
\hline \multirow{4}{*}{ Ala } & GCT & $2 \cdot 0$ & 1.6 & $2 \cdot 7$ & $2 \cdot 6$ \\
\hline & GCC & $0 \cdot 4$ & 0.4 & 0.7 & $2 \cdot 2$ \\
\hline & GCA & $3 \cdot 1$ & $1 \cdot 2$ & $4 \cdot 6$ & $2 \cdot 3$ \\
\hline & GCG & $0 \cdot 4$ & $0 \cdot 6$ & $0 \cdot 7$ & $3 \cdot 2$ \\
\hline
\end{tabular}

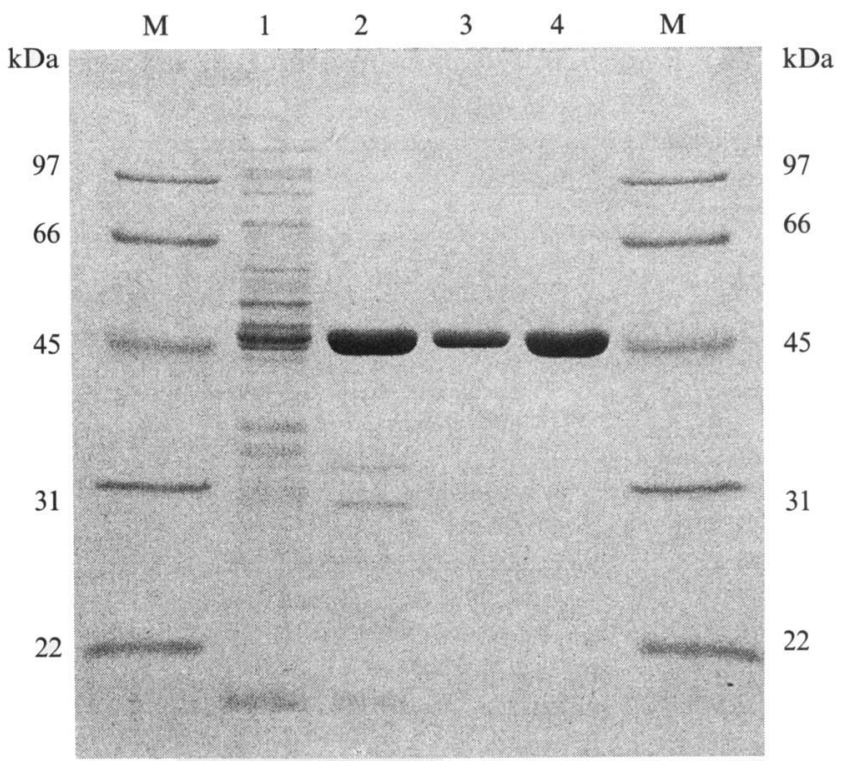

Fig. 4. SDS-PAGE analysis of the thermostable $T$. saccharolyticum strain B6A-RI xylose isomerase expressed in E. coli (pZXI6). Lane M, molecular mass markers; lane 1, crude extract; lane 2, after heat treatment; lane 3, after anion exchange chromatography; lane 4, after gel filtration.

T. saccharolyticum strain B6A-RI which are involved in xylan degradation. $x y n A$ and $x y n B$ were closely linked on a chromosome of $T$. saccharolyticum strain B6A-RI (Lee, 1992). Average codon usage for E. coli (AllfSteinberger, 1984) is included for comparison. The patterns of codon usage among the three genes were very similar to each other. There is a clear propensity toward AT-containing isocodons, and this probably results from the low $\mathrm{G}+\mathrm{C}$ content $(36 \mathrm{~mol} \%$ ) of this organism.

\section{Biochemical characterization of cloned xylose isomerase}

The thermostable $T$. saccharolyticum strain B6A-RI xylose isomerase expressed in $E$. coli was purified to homogeneity (Fig. 4). Heat treatment of cell extracts at $85^{\circ} \mathrm{C}$ for $15 \mathrm{~min}$ was a very efficient purification step for the enzyme from E. coli, as approximately $90 \%$ of $E$. coli proteins could be removed by this procedure. After heat treatment, the purification yield increased 18-fold. After additional purification by anion-exchange chromatography and gel filtration, preparations of homogeneous recombinant xylose isomerase were obtained and their purity was demonstrated by SDS-PAGE (Fig. 4). The purified enzyme consisted of one type of subunit with a molecular mass of $50 \mathrm{kDa}$. The molecular mass of the purified recombinant enzyme was $200 \mathrm{kDa}$, indicating that the enzyme is a tetramer composed of identical subunits.

The apparent temperature and $\mathrm{pH}$ optima for activity of the cloned xylose isomerase were $80^{\circ} \mathrm{C}$ and $7 \cdot 0$ to $7 \cdot 5$, 
respectively. The enzyme was stable at $80{ }^{\circ} \mathrm{C}$ for $60 \mathrm{~min}$, and $0.5 \mathrm{~mm}-\mathrm{Co}^{2+}$ and $5 \mathrm{~mm}-\mathrm{Mg}^{2+}$ were required for optimum enzyme activity and thermostability.

\section{Discussion}

Xylose isomerase is an important industrial enzyme (Antrim et al., 1979; Bucke, 1980) because of its ability to catalyse the conversion of glucose to fructose. Xylose isomerases from thermophilic bacteria have high temperature optima and are thermostable, indicating their potential use for the commercial conversion of starch to high-fructose corn syrup at high temperature with increased fructose yield.

Xylose isomerases have been isolated and studied from many micro-organisms. $x y l$ genes from $E$. coli (Schellenberg et al., 1984), B. subtilis (Wilhelm \& Hollenberg, 1984, 1985), Thermus thermophilus (Dekker et al., 1991a), S. violaceoniger (Marcel et al., 1987), Thermoanaerobacter ethanolicus 39E (Dekker et al., 1991b) and T. thermosulfurigenes 4B (Lee et al., 1990b) have been cloned and sequenced. Comparison of the primary structure of xylose isomerases from three thermophilic anaerobic bacteria, $T$. saccharolyticum strain B6A-RI, $T$. thermosulfurigenes $4 \mathrm{~B}$ and Thermoanaerobacter ethanolicus 39E, indicate extensive similarities between the enzymes from these organisms. Because these strains have evolved in thermal hotsprings in Yellowstone National Park (Lee et al., 1993; Schink \& Zeikus, 1983) these organisms might have a common phylogenic origin with conservation of xylose isomerase, or alternatively, gene transfer might have occurred between them.

In several bacteria in which the genetic organization of the $x y l$ genes has been examined, the xylose isomerase and xylulose kinase genes were found to be part of one operon (Ghangas \& Wilson, 1984; Lawlis et al., 1984; Wilhelm \& Hollenberg, 1984). Another ORF with the same transcriptional orientation was found downstream of xylA from the cloned DNA fragment from $T$. saccharolyticum strain B6A-RI (data not shown) and this may be a xylulose kinase gene $(x y l B)$.

The predicted molecular mass of $50474 \mathrm{Da}$, calculated from the deduced amino acid sequence, is in good agreement with the subunit molecular mass of $50 \mathrm{kDa}$ reported for xylose isomerase purified from $T$. saccharolyticum strain B6A (formerly Thermoanaerobacter strain B6A) (Lee \& Zeikus, 1991). The recombinant protein was purified to homogeneity and its physical and biochemical properties were determined. The molecular mass of the purified recombinant xylose isomerase was $200 \mathrm{kDa}$, indicating that the enzyme is a tetramer composed of identical subunits, and both enzymes had the same $\mathrm{N}$-terminal sequence. This result is similar to that for the native xylose isomerase from $T$. saccharo- lyticum strain B6A (Lee \& Zeikus, 1991), and the two xylose isomerases also displayed identical $\mathrm{pH}$ and temperature optima, thermostability, and metal ion requirements.

The base composition of the coding region of $x y l A$ is $39.7 \mathrm{~mol} \% \mathrm{G}+\mathrm{C}$, a value that is close to the $\mathrm{G}+\mathrm{C}$ content $(36 \mathrm{~mol} \%)$ of this organism (Lee et al., 1993). The low $\mathrm{G}+\mathrm{C}$ content of $T$. saccharolyticum strain B6ARI $x y l A$ results in an extremely biased usage of the bases, $A$ or $T$, which were present in the third position of all dominant codons examined in this organism.

The high thermostability of $T$. saccharolyticum strain B6A-RI xylose isomerase made it possible to use heat treatment as a very efficient step in purifying the cloned enzyme produced in the mesophilic host $E$. coli. The presence of metal ions $\left(\mathrm{Mg}^{2+}\right.$ and $\left.\mathrm{Co}^{2+}\right)$ and a high protein concentration in cell extracts were essential for optimal recovery of the enzyme during heat treatment. The thermostable xylose isomerase produced by the recombinant plasmid pZXI6 was one of the most abundant proteins in $E$. coli.

The catalytic mechanism for xylose isomerase was originally believed to involve histidine-directed general base catalysis (Rose et al., 1969). Lee et al. (1990 b) identified the active site histidine residues of xylose isomerase from $T$. thermosulfurigenes $4 \mathrm{~B}$ by site-directed mutagenesis, and found that $\mathrm{His}^{101}$ was the only essential histidine residue involved directly in catalysis. The ratelimiting step in the isomerization reaction was found to be hydrogen transfer and not substrate ring opening.

At present, the molecular mechanism underlying the high thermophilicity (i.e., temperature optimum for activity at $80^{\circ} \mathrm{C}$ and thermostability at $85^{\circ} \mathrm{C}$ ) of this enzyme is not clear. This problem could be addressed through the use of nested deletion mutants to identify gene regions which are responsible for activity and thermostability.

This material is based upon work supported by the Cooperative State Research Service, US Department of Agriculture, under Agreement No. 90-34189-5014. In addition we would like to thank Sue Lowe for her valuable suggestions in this research and for her help in the preparation and completion of this manuscript.

\section{References}

AllF-STEINBERGER, C. (1984). Evidence for a coding pattern on the non-coding strand of the E. coli genome. Nucleic Acids Research 12, 2235-2241.

Antrim, R. L., Colliala, W. \& Schnyder, B. J. (1979). Glucose isomerase production of high-fructose syrups. In Applied Biochemistry and Bioengineering, pp. 97-155. Edited by L. B. Wingard. New York: Academic Press.

Bachmann, B. J. (1972). Pedigrees of some mutant strains of Escherichia coli K-12. Bacteriological Reviews 36, 525-557.

Birnboim, H. C. \& Doly, J. (1979). A rapid alkaline extraction 
procedure for screening recombinant plasmid DNA. Nucleic Acids, Research 7, 1513-1523.

BraDFORD, M. M. (1976). A rapid and sensitive method for quantitation of microgram quantities of protein utilizing the principle of protein-dye binding. Analytical Biochemistry 72, 248-254.

BUCKE, C. (1980). Enzymes in fructose manufacture. In Enzymes and Food Processing, pp. 51-72. Edited by G. G. Birch, N. Blackebrough and J. K. Parker. London: Applied Science Publishers.

Clewell, D. B. (1972). Nature of Col El plasmid replication in Escherichia coli in the presence of chloramphenicol. Journal of Bacteriology 110, 667-676.

Dekker, K., Yamagata, H., Sakaguchi, K. \& Udaka, S. (1991a). Xylose (glucose) isomerase gene from the thermophile Thermus thermophilus: cloning, sequencing, and comparison with other thermostable xylose isomerases. Journal of Bacteriology 173, 3078-3083.

Dekker, K., Yamagata, H., SaKaguchi, K. \& Udaka, S. (1991b). Xylose (glucose) isomerase gene from the thermophile Clostridium thermohydrosulfuricum: Cloning, sequencing, and expression in Escherichia coli. Agricultural and Biological Chemistry 55, 221-227.

Devereux, J., HaEberLi, P. \& Smithies, O. (1984). A comprehensive set of sequence analysis programs for the VAX. Nucleic Acids Research 12, 387-395.

Drocourt, D., Bejar, S., Calmels, T., Reynes, J. P. \& Tiraby, G. (1988). Nucleotide sequence of the xylose isomerase gene from Streptomyces violaceoniger. Nucleic Acids Research 16, 9337.

HaSTUP, S. (1988). Analysis of the Bacillus subtilis xylose regulon. In Genetics and Biotechnology of Bacilli, vol. 2, pp. 79-83. Edited by A. T. Granesan \& J. A. Hoch. New York: Academic Press.

GHANGAS, G. S. \& WILSON, D. B. (1984). Isolation and characterization of the Salmonella typhimurium LT2 xylose regulon. Journal of Bacteriology 157, 158-164.

Kreuzer, P., Gartner, D., Allmansberger, R. \& Hillen, W. (1989). Identification and sequence analysis of the Bacillus subtilis W23 $x y / \mathrm{R}$ gene and $x y l$ operator. Journal of Bacteriology 171, 3840-3845.

LaWlis, V. B., Dennis, M. S., Chen, E. Y., SMith, D. H. \& HenNer, D. J. (1984). Cloning and sequencing of the xylose isomerase and xylulose kinase genes of Escherichia coli. Applied and Environmental Microbiology 47, 15-21.

LeE, C. \& Zeikus, J. G. (1991). Purification and characterization of thermostable glucose isomerase from Clostridium thermosulfurogenes and Thermoaerobacter strain B6A. Biochemical Journal 273, 565-571.

LeE, C., SAHA, B. C. \& Zeikus, J. G. (1990a). Characterization of Thermoanaerobacter glucose isomerase in relation to saccharidase synthesis and development of single-step processes for sweetener production. Applied and Environmental Microbiology 56, 2895-2901.

Lee, C., Bhatnagar, L., Saha, B. C., Lee, Y.-E., Takagi, M., Imanaka, T., Bagdasarian, M. \& Zeikus, J. G. (1990 $b$ ). Cloning and expression of the Clostridium thermosulfurogenes glucose isomerase gene in Escherichia coli and Bacillus subtilis. Applied and Environmental Microbiology 56, 2638-2643.

Lee, C., Bagdasarian, M., Meng, M. \& Zeikus, J. G. $(1990 c)$. Catalytic mechanism of xylose (glucose) isomerase from Clostridium thermosulfurogenes. Journal of Biological Chemistry 265, 19082-19090.

LEE, Y.-E. (1992). Molecular physiology of xylan degradation by thermoanaerobes. PhD thesis, Michigan State University, Michigan, USA.
Lee, Y.-E., JAIN, M. K., LeE, C., Lowe, S. E. \& Zeikus, J. G. (1993). Taxonomic distinction of saccharolytic thermoanaerobes: Description of Thermoanaerobium xylanolyticum gen. nov., sp. nov. and Thermoanaerobium saccharolyticum sp. nov. Reclassification of Thermoanaerobium brockii, Clostridium thermosulfurogenes and Clostridium thermohydrosulfuricum E100-69 as Thermoanaerobacter brockii comb. nov., Thermoanaerobacterium thermosulfurigenes comb. nov. and Thermoanaerobacterium thermohydrosulfuricus comb. nov., and transfer of Clostridium thermohydrosulfuricum $39 \mathrm{E}$ to Thermoanaerobacter ethanolicus. International Journal of Systematic Bacteriology 43, 41-51.

Marcel, T., DrocourT, D. \& Tiraby, G. (1987). Cloning of the glucose isomerase (D-xylose isomerase) and xylulose kinase genes of Streptomyces violaceoniger. Molecular and General Genetics 208, 121-126.

MARMUR, J. (1961). A procedure for the isolation of deoxyribonucleic acid from microorganisms. Journal of Molecular Biology 3, 208-218.

Mclaughlin, J. R., Murray, C. L. \& Rabinowitz, J. C. (1981). Unique features in the ribosome binding site sequence of the Grampositive Staphylococcus aureus $\beta$-lactamase gene. Journal of Biological Chemistry 256, 11283-11291.

Perbal, B. (1988). A Practical Guide to Molecular Cloning, 2nd edn. New York: John Wiley \& Sons.

Rose, I. A., O'Connell, E. L. \& Mortlock, R. P. (1969). Stereochemical evidence for a cis-enediol intermediate in Mn-dependent aldose isomerases. Biochimica et Biophysica Acta 178, 376-379.

Sambrook, J., Fritsch, E. F. \& Maniatis, T. (1989). Molecular Cloning: A Laboratory Manual, 2nd edn. Cold Spring Harbor, NY: Cold Spring Harbor Laboratory Press.

SANGer, F., Nicklen, S. \& Coulson, A. R. (1977). DNA sequencing with chain-terminating inhibitors. Proceedings of the National Academy of Sciences of the United States of America 74, 5463-5467.

SchellenberG, G. D., Sarthy, A., Larson, A. E., Backer, M. P., Crabb, J. W., Lidstrom, M., HaLl, B. D. \& Furlong, C. E. (1984). Xylose isomerase from Escherichia coli: characterization of the protein and the structural gene. Journal of Biological Chemistry 259, 6826-6832.

Schink, B. \& Zeikus, J. G. (1983). Clostridium thermosulfurogenes sp. nov., a new thermophile that produces elemental sulphur from thiosulphate. Journal of General Microbiology 129, 1149-1158.

Stormo, G. D., SchNeIDER, T. D. \& Gold, L. (1982). Characterization of translational initiation sites in E. coli. Nucleic Acids Research 10, 2971-2996.

WilHeLm, M. \& Hollenderg, C. P. (1984). Selective cloning of Bacillus subtilis xylose isomerase and xylulose kinase in Escherichia coli genes by IS 5-mediated expression. EMBO Journal 3, 2555-2560.

Wilhelm, M. \& Hollenberg, C. P. (1985). Nucleotide sequence of the Bacillus subtilis xylose isomerase gene: extensive homology between the Bacillus and Escherichia coli enzymes. Nucleic Acids Research 13, $5717-5723$.

Wong, H. C., Ting, Y., Lin, H.-C., Reichert, F., Myambo, K., Watt, K. W., ToY, P. L. \& Drummond, R. J. (1991). Genetic organization and regulation of the xylose degradation genes in Streptomyces rubiginosus. Journal of Bacteriology 173, 6849-6858.

Zeikus, J. G., Ben-Bassat, A. \& Hegge, P. (1980). Microbiology of methanogenesis in thermal volcanic environments. Journal of Bacteriology 143, 432-440.

Zhang, H., Scholl, R., Browse, J. \& Somerville, C. (1988). Double stranded DNA sequencing as a choice for DNA sequencing. Nucleic Acids Research 16, 1220. 